\begin{tabular}{l} 
Jpn. J. Pharm. Health Care Sci. \\
\hline ノ -
\end{tabular}

\title{
各種輸液斉の滴容量と変動要因
}

\author{
橋本大佑 ${ }^{*}$, 加賀順二，藤田佳代子 , 岩本哲史 \\ 株式会社大塚製薬工場輸液情報センター
}

\section{Study on Droplet Volumes of Parenteral Nutrition Solutions during Administration}

\author{
Daisuke Hashimoto*, Junji Kaga, Kayoko Fujita and Tetsuji Iwamoto \\ Information Center for Infusion Therapy and Product, Otsuka Pharmaceutical Factory, Inc. \\ $\left[\begin{array}{l}\text { Received June 24, } 2008 \\ \text { A ccepted December 11, } 2008\end{array}\right]$
}

\begin{abstract}
In parenteral nutrition, each intravenous solution has an optimum infusion rate and proper management of administration is a very important issue. In the case of not using an infusion pump (gravity infusion) and using an infusion pump which controls the number of droplets, the administered volume depends on the droplet size, i.e. droplet volume. While the Minis try of Health, Labour and Welfare (Bulletin No. 112) specifies the number of droplets per $\mathrm{mL}$ for intravenous administra tion sets, there is a lack of information on how the physical characteristics of solutions affect droplet volume. Therefore, in the present study, we investigated droplet volume for various intravenous solutions during administration and found that the solution density, surface tension (solutions with and without surfactants), and infusion rate all affect droplet volume.
\end{abstract}

Key words — droplet volume, density, surfactant, infusion rate

\section{緒言}

輸液療法は, 水分補給, 電解質是正および栄養補給な ど，さまざまな目的で用いられ，医療上欠かせないもの となっている。近年, 中心静脈栄養療法や末梢静脈栄養 療法などの発展に伴い種々の輸液剤が医療現場に供さ

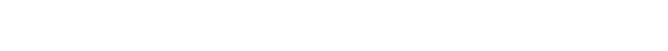

輸液阂の投与速度は各々の薬剂で規定され，投与時に 点滴速度を適切に管理することは, 輸液療法上, 重要な 管理項目の一つである．医療現場て輸液剂が投与される 際，流量制御方式の輸液ポンプの使用も見受けられる が, 自然滴下法や滴下制御方式の輸液ポンプを用いて滴 数を制御して点滴されることが一般的である.輸液セッ 卜の点滴筒(ドリップチャンバー)内で滴下する液滴の数 は目視または機械的に計数され，液滴の大きさ(滴容量) を乗じて単位時間あたりの輸液投与量が算出される .こ こで滴容量は点滴投与時の輸液投与量の決定因子であ り，密度，表面張力および粘度などの液谷のものの物性 や点滴速度などに影響されることが報告されてい る ${ }^{1-4)}$.しかし, 各種の輸液剂兴のものを対象とした滴 容量の検討は少ない .

一方, 平成 17 年 3 月 25 日付厚生労働省告示 112 号に
より, 輸液セットの点滴口サイズに関して, 国際規格で あるISO 規格と整合を図り，日本工業規格として基準 が示された .これを受け, 輸液セットの点滴ロサイズは 平成 21 年 4 月以降, 20 滴 $/ \mathrm{mL}$ および 60 滴/ $\mathrm{mL}$ に統一 されることとなった5.

これらの背景から，われわれは，20滴/mL および 60 滴 $/ \mathrm{mL}$ の輸液セットを用いて, 各種輸液剂について滴 容量の測定を行い, 輸液斉の種類と滴容量の関係や種々 の変動因子(密度, 表面張力, 粘度, 点滴速度および輸 液セットの滴数規格等)の影響について検討を行った .

\section{実 験 方 法}

\section{1. 材料(表 1 4)}

表 1 に示す 26 種類の輸液剂を試験検体とした 。これ らの輸液剂の組成を表 2 に示す．また，輸液剂に配合さ れる薬剤として表 3 に示す薬剤を用いた 。

一方, 試験に供した輸液セットを表 4 に示す．JMS 輸液セット 210 型(規格 : 20 滴 $/ \mathrm{mL}, \mathrm{PVC}$ )を基準として 各種輸液剂の滴容量の比較を行った。しかし, 輸液阂や 配合薬斉の添付文書上でPVC フリーの輸液セットの使 用が規定されている輸液斉の試験, 点滴速度を微量で正 確に管理する必要が考えられる輸液斉の試験，滴容量を

\footnotetext{
徳島県鳴門市撫養町立岩字芥原 115 ; 115, A za Kuguhara, Tateiwa, Muyacho, Naruto-shi, Tokushima, 772-8601 Japan
} 
表 1 . 試験に供した輸液剂

\begin{tabular}{|c|c|c|c|c|c|}
\hline $\begin{array}{c}\text { 輸啵䖈 } \\
\text { No. }\end{array}$ & 峢吊名 & 产器 & $\begin{array}{c}\text { 容量 } \\
(\mathrm{mL})\end{array}$ & Lot No. & 蒜效分類 \\
\hline 1 & 大塚生食注 & Single Bag & 500 & M7L83 & 向液代刀削 \\
\hline 2 & ラタデック畩 & Single Bag & 500 & M7K90 & 向液代刀剂 \\
\hline 3 & ポタコール R & Single Bag & 500 & M6G94 & 向洲代刀狱 \\
\hline 4 & KN 補啵 3B & Single Bag & 500 & M6L87 & 血液代用绪 \\
\hline 5 & フィジオ゚140 & Single Bag & 500 & M6K89 & 血澓代用剂 \\
\hline 6 & フィジオ935 & Single Bag & 500 & M7I79 & 山液代用剂 \\
\hline 7 & トリフリード鳥 & Single Bag & 500 & $\mathrm{~K} 7 \mathrm{~B} 75$ & 山液代用剂 \\
\hline 8 & 低分子デキストランL 社 & Single Bag & 500 & $\mathrm{~K} 7 \mathrm{H} 90$ & 自液代用剂 \\
\hline 9 & 低分子デキストラン稙往 & Single Bag & 500 & $\mathrm{~K} 7 \mathrm{D} 78$ & 向浓代刀削 \\
\hline 10 & マルトス -10 & Single Bag & 500 & M5F83 & 䊒類佣 \\
\hline 11 & 人塚䊀滩 $10 \%$ & Single Bag & 500 & M6177 & 栯類剂 \\
\hline 12 & 大塚糖液 $50 \%$ & Single Bag & 500 & M6B89 & 糖類威 \\
\hline 13 & トリバレンの1 号 & Single Bag & 600 & M7F84 & 粕類剂 \\
\hline 14 & トリハレンタ 号 & Single Bag & 600 & M7B82 & 傏類刘 \\
\hline 15 & フ’ミパレンか & Single Bag & 400 & K6D83 & 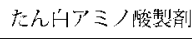 \\
\hline 16 & デミノレバンか & Single Bag & 500 & K6E81 & 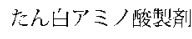 \\
\hline 17 & アミノフリード & Double Bag & 500 & M7I96 & たん白アミノ酸製剂 \\
\hline 18 & ビーフリードッ点滴静注用 & Double Bag & 500 & M7I90 & たん白アミノ酸製洞 \\
\hline 19 & アミノトリパ1号 & Double Bag & 850 & $\mathrm{~K} 7 \mathrm{~J} 77$ & たんウクミノ酸製剂 \\
\hline 20 & ソミノトリバ 2 号 & Double Bag & 900 & $\mathrm{~K} 7 \mathrm{H} 76$ & たんウグミノ酸製剂 \\
\hline 21 & ネオパレン雨 1 号 & Double Bag & 1000 & K7J86 & たんウプミノ酸"留剂 \\
\hline 22 & ネオハレン 2 号 & Double Bag & 1000 & $\mathrm{~K} 7 \mathrm{~K} 77$ & たんヒア゚ミノ酸製剂 \\
\hline 23 & ミキシッド囘ーL & Double Bag & 900 & T7D87 & たん甘グミノ睃製剤 \\
\hline 24 & ミキシッド仍一H & Double Bag & 900 & T7D82 & たん白アミノ酸製舦 \\
\hline 25 & イントラリポス゚ $10 \%$ & Single Bag & 250 & T7J00 & その他の㶌養強壮楽 \\
\hline 26 & 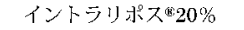 & Single Bag & 250 & T5G75 & その他の滋香強壮薬 \\
\hline
\end{tabular}

※試験に供した輸液剤の製造販売元は，すべて株式会社大塚製薬工場

表 2 . 各種輸液斉の組成

\begin{tabular}{|c|c|c|c|c|c|c|c|c|c|c|c|c|c|}
\hline \multirow{3}{*}{$\begin{array}{c}\text { 輸液剂 } \\
\text { No. }\end{array}$} & \multirow{3}{*}{ 製出名 } & \multirow{2}{*}{\multicolumn{3}{|c|}{$\frac{\text { 糖・アミノ酸・脂肘 }}{(\mathrm{g} / \mathrm{L})}$}} & \multicolumn{9}{|c|}{ 之な霆解質維L成 } \\
\hline & & & & & \multicolumn{7}{|c|}{$(\mathrm{mEq} / \mathrm{L})$} & \multirow{2}{*}{$\frac{(\mathrm{mmol} / \mathrm{L})}{\mathrm{P}}$} & \multirow{2}{*}{$\frac{(\mu \mathrm{mol} / \mathrm{L})}{\mathrm{Zn}}$} \\
\hline & & 糖質 & 宁ミノ酸 & 脂質 & $\mathrm{Na}^{+}$ & $\mathrm{K}^{+}$ & $\mathrm{Ca}^{2+}$ & $\mathrm{Mg}^{2+}$ & $\mathrm{Cl}^{-}$ & 呸酸イオン & 乳酸イオン & & \\
\hline 1 & 人塚生食汒 & - & - & - & 154 & - & - & - & 154 & - & - & - & - \\
\hline 2 & ラクテック网泣: & & & & 130 & 4 & 3 & & 109 & & 28 & & \\
\hline 3 & ポタコール R & $50^{* 1}$ & - & - & 130 & 4 & 3 & - & 109 & - & 28 & - & - \\
\hline 4 & $\mathrm{KN}$ 補淮 3B & $27^{* 2}$ & - & - & 50 & 20 & - & - & 50 & - & 20 & - & - \\
\hline 5 & フィジオイ140 & $10^{+2}$ & - & - & 140 & 4 & 3 & 2 & 115 & 25 & - & - & - \\
\hline 6 & フィジオ 35 & $100^{\star 2}$ & - & - & 35 & 20 & 5 & 3 & 28 & 20 & - & 10 & - \\
\hline 7 & トリフリードタ & $105^{\text {* } \mathrm{s}}$ & - & - & 35 & 20 & 5 & 5 & 35 & 6 & - & 10 & 5 \\
\hline 8 & 低分〕デキストランL 注: & - & - & - & 130 & 4 & 3 & - & 109 & - & 28 & - & - \\
\hline 9 & 低分子デキストラン糖汗 ${ }^{*}{ }_{4}$ & $50^{* 2}$ & - & - & - & - & - & - & - & - & - & - & - \\
\hline 10 & マルトス ${ }^{\mathbb{R}}-10$ & $100^{* 1}$ & - & - & - & - & - & - & - & - & - & - & - \\
\hline 11 & 人塚糖液 $10 \%$ & $100^{* 2}$ & & & & & & & & & & & \\
\hline 12 & 大堟料淮 $50 \%$ & $500^{* 2}$ & - & - & - & - & - & - & - & - & - & - & - \\
\hline 13 & トリパレン心 1 客 & $233^{* 3}$ & - & - & 5 & 45 & 8 & 8 & 15 & 10 & - & 10 & 17 \\
\hline 14 & トリパレン®2 $\frac{1 t}{j}$ & $292^{* 3}$ & - & - & 58 & 45 & 8 & 8 & 73 & - & - & 10 & 17 \\
\hline 15 & アミパレン日 & - & 100 & - & 2 & - & - & - & - & 120 & - & - & - \\
\hline 16 & アミノレバンタ & - & 80 & - & 14 & - & - & - & 94 & - & - & - & - \\
\hline 17 & アミノフリード、 & $75^{* 2}$ & 30 & & 35 & 20 & 5 & 5 & 35 & 13 & 20 & 10 & 5 \\
\hline 18 & ビーフリード点滴静犯用 & $75^{* 2}$ & 30 & - & 35 & 20 & 5 & 5 & 35 & 16 & 20 & 10 & 5 \\
\hline 19 & アミノトリパ 1号 & $164^{* 3}$ & 29 & - & 41 & 26 & 5 & 5 & 41 & 52 & - & 6 & 9 \\
\hline 20 & アミノトリパ、2号 & $195^{* 3}$ & 33 & - & 39 & 30 & 6 & 6 & 39 & 60 & - & 7 & 11 \\
\hline 21 & ネオパレンタ1光”5 & $120^{* 2}$ & 20 & - & 50 & 22 & 4 & 4 & 50 & 47 & - & 5 & 20 \\
\hline 22 & 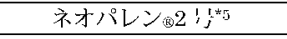 & $175^{\text {*2 }}$ & 30 & - & 50 & 27 & 5 & 5 & 50 & 53 & - & 6 & 20 \\
\hline 23 & ミキシッドツー $\mathrm{L}^{* 6}$ & $122^{* 2}$ & 33 & 17 & 39 & 30 & 9 & 6 & 49 & 28 & - & 5 & 11 \\
\hline 24 & ミキシッドかー $\mathrm{H}^{* 6}$ & $167^{\text {츠 }}$ & 33 & 22 & 39 & 30 & 9 & 6 & 45 & 28 & - & 7 & 11 \\
\hline 25 & イントラリポス田10\% & & & 100 & & & & & & & & & \\
\hline 26 & イントラリポズ $20 \%{ }^{* 6}$ & - & - & 200 & - & - & - & - & - & - & - & - & - \\
\hline
\end{tabular}

*1: マルトース ${ }^{*} 2$ : ブドウ糖 ${ }^{*} 3:$ ブドウ糖・果糖・キシリトール $=4 \cdot 2 \cdot 1{ }^{*} 4:$ デキストラン 40 を含む

*5 : 界面活性剂(ポリソルベート 20,80 )を含む。 ${ }^{*} 6$ : 界面活性剂(精製卵黄レシチン)を含む． 
表 3 . 配合薬剂

\begin{tabular}{|c|c|c|c|c|}
\hline 製品名 & 挸格·単位 & 製造販壳元 & Lot No. & $\begin{array}{c}\text { 主な界面活性成分 } \\
\text { (分量) }\end{array}$ \\
\hline オーツカMV往 & $\begin{array}{c}1 \text { 瓶 } 1 \text { 管 } \\
1 \text { 組 }\end{array}$ & （株）大塚製薬丁場 & 7K84MV1 & $\begin{array}{l}\text { ポリソルベート }-80(40 \mathrm{mg}) \\
\text { ポリソルベート }-20(8 \mathrm{mg})\end{array}$ \\
\hline エレメンミックタ注 & $\begin{array}{l}2 \mathrm{~mL} \\
1 \text { 管 }\end{array}$ & 味の素 (怢) & $7 \mathrm{~L} 326 \mathrm{~A}$ & - \\
\hline ケイツーツ N 静注用 & $\begin{array}{l}10 \mathrm{mg} \\
1 \text { 管 }\end{array}$ & エーザイ(株) & $62 \mathrm{C} 01 \mathrm{M}$ & 精製ダイズレシチン（16mg） \\
\hline $\begin{array}{l}\text { 強力ネオミノ } \\
\text { ファゲンシー@ }\end{array}$ & $\begin{array}{l}20 \mathrm{~mL} \\
1 \text { 管 }\end{array}$ & $\begin{array}{l}\text { (株) ミノファーゲ } \\
\text { ン製薬 }\end{array}$ & G1197 & $\begin{array}{l}\text { グリチルリチン酸モノアンモ } \\
\text { ニウム }(53 \mathrm{mg})\end{array}$ \\
\hline ラスデット注 & $\begin{array}{c}100 \mathrm{mg} 5 \mathrm{~mL} \\
1 \text { 胡 }\end{array}$ & 日本化薬（株） & 571500 & ポリソルベートー $-80(400 \mathrm{mg})$ \\
\hline $\begin{array}{c}\text { サンディミェン゙ } \\
\text { 注射液 }\end{array}$ & $\begin{array}{c}5 \% 5 \mathrm{~mL} \\
1 \text { 管 }\end{array}$ & $\begin{array}{l}\text { ノバルティス } \\
\text { ファーマ(株) }\end{array}$ & P0032 & $\begin{array}{c}\text { ポリオキシエチレンヒマシ油 } \\
(3.25 \mathrm{~g})\end{array}$ \\
\hline
\end{tabular}

表 4 . 試験に供した輸液セット

\begin{tabular}{|c|c|c|c|c|c|}
\hline $\begin{array}{l}\text { セット } \\
\text { セ澈号 }\end{array}$ & 製品名 & 规格 & 品筬 & Lot $N_{0}$ & 製造販売元 \\
\hline A & JMS 輸液セット 210 型 & $\begin{array}{c}20 \text { 滴/mL } \\
\text { PVC }\end{array}$ & JY-A343L & 070613.12 & $\begin{array}{l}\text { (株) ジエイ・ } \\
\text { エム・エス }\end{array}$ \\
\hline B & JMS 輸液セット 210 型 & $\begin{array}{c}20 \text { 滴 } / \mathrm{mL} \\
\mathrm{PVC} \text { フリー }\end{array}$ & $\begin{array}{c}\mathrm{JY}- \\
\mathrm{PB} 343 \mathrm{~L} \\
\end{array}$ & 071019.07 & $\begin{array}{l}\text { (怢) ジェイ・ } \\
\text { エム・エス }\end{array}$ \\
\hline $\mathrm{C}$ & $\begin{array}{c}\text { テルフュージョン时 } \\
\text { 輸液セット }\end{array}$ & $\begin{array}{c}20 \text { 滴 } / \mathrm{mL} \\
\text { PVC }\end{array}$ & $\mathrm{TI}-\mathrm{U} 350 \mathrm{P}$ & $070620 \mathrm{~A}$ & テルモ（株） \\
\hline $\mathrm{D}$ & ニプロ輸液セット & $\begin{array}{c}20 \text { 滴 } / \mathrm{mL} \\
\mathrm{PVC} \\
\end{array}$ & $\begin{array}{c}\text { ISA- } \\
200 \mathrm{E} 00 \mathrm{Z} \\
\end{array}$ & $07 \mathrm{C} 20 \mathrm{~A}$ & ニブロ（株） \\
\hline a & JMS 輸液セット 210 型 & $\begin{array}{c}60 \text { 滴/mL } \\
\text { PVC }\end{array}$ & $J Y-A 313 L$ & 071030.14 & $\begin{array}{l}\text { (株) ジェイ・ } \\
\text { エム・エス }\end{array}$ \\
\hline $\mathrm{b}$ & JMS 榆液セット 210 型 & $\begin{array}{c}60 \text { 滳 } / \mathrm{mL} \\
\mathrm{PVC} フ ォ-\end{array}$ & $\begin{array}{c}\text { JY- } \\
\text { PB313L }\end{array}$ & 070906.10 & $\begin{array}{l}\text { (株) ジェイ・ } \\
\text { エム・エス }\end{array}$ \\
\hline$c$ & $\begin{array}{c}\text { テルフュージョン旬 } \\
\text { 輸液セット }\end{array}$ & $\begin{array}{c}60 \text { 滴 } / \mathrm{mL} \\
\mathrm{PVC} \\
\end{array}$ & $\begin{array}{c}\mathrm{TK}- \\
\mathrm{U} 350 \mathrm{P} 027 \\
\end{array}$ & $0071022 \mathrm{~A}$ & テルモ（株） \\
\hline d & ニプロ輸液セツト & $\begin{array}{c}60 \text { 滴 } / \mathrm{mL} \\
\text { PVC }\end{array}$ & $\begin{array}{c}\text { ISP- } \\
102 \mathrm{E} 00\end{array}$ & $08 \mathrm{~A} 11 \mathrm{~A}$ & ニプロ（株） \\
\hline
\end{tabular}

輸液セット間で比較する試験には，乥れぞれの試験の目 的に応じて他の輸液セットを使用した .

輸液ポンプは，臨床現場で広く使用されている自然滴 下法が滴数による投与量制御である現状を踏まえ，滴数 制御方式の JMS 輸液ポンプ OT-701型(株)ジェイ・エ ム・エス), JMS 輸液ポンプ OT-707型(株)ジェイ・エ ム・エス)およびテルフュージョン・輸液ポンプTE-131 (テルモ(株))を使用した .

\section{2. 輸液剂の密度および粘度の測定方法}

1)密度

日局 15 における比重および密度測定法のにより，20ㄷ における密度を測定した 。

\section{2)粘度}

日局 15 における粘度測定法》により，20ㄷ における 各輸液剂(No.1〜20)の粘度を測定した。

\section{3. 滴容量の測定方法}

日本工業規格(JS)で定められている点滴型輸液ポンプ の正確度試験8における試験方法を参考にして滴容量の 測定を行った .すなわち, 輸液阂のバッグに未使用の輸 液セットを装着して, 輸液ポンプに取り付け, 輸液セッ 卜の先に付けた注射針(18G)の先端をポンピング室の中 央と同じ高さにあわせ , 注射針の先端から輸液斉のバッ グ内の薬液面までの高さを $50 \mathrm{~cm}$ に固定した(図 1) . 室 温 $\left(23 \pm 1^{\circ} \mathrm{C}\right)$ 下において, 輸液ポンプを各試験で規定し た点滴速度で運転を開始し，運転開始から 15 分間点滴 速度の安定化を行った後，正確に 60 分間滴下を行い， 乥の間に滴下した滴数と薬液の体積から滴容量を求め た．滴容量に関しては，弚れ光れの検体につき 3 種類の 輸液ポンプを 1 回ずつ使用して計 3 回の測定を行い, 光 の平均値および標準偏差を求めた . 
結果

1. 各種輸液斉の滴容量

種々の輸液剂の密度，粘度および滴容量の測定結果を 表 5 に示した，滴容量は，点滴速度および輸液セットの 種類の影響を受けることが考えられるため, 点滴速度は $250 \mathrm{~mL} /$ 時間に, 輸液セットは A〔JMS 輸液セット 210 型(規格：20 滴/mL，PVC)]に固定して滴容量を測定し

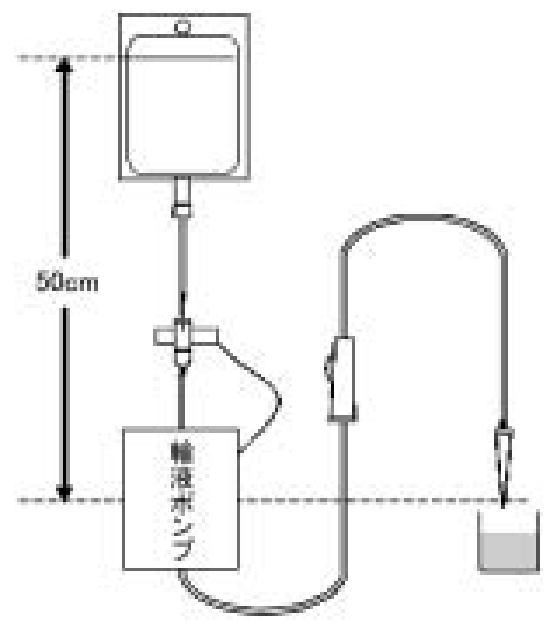

図 1 . 滴容量測定の概略図
た .なお，表面張力に明らかに影響を与えることが予想 されるポリソルベートや精製卵黄レシチンなどの界面活 性成分を含む輸液斉(No.21～26)は試験検体から除いた．

中心静脈栄養輸液剂および脂肪乳剂は，可溶化剂を含 有するオーツカ MV 注などの総合ビタミン剂を配合し たり，輸液剂产のものに精製卵黄レシチンなどの可溶化 剂を含むことから，可塑剂(DEHP)を含まない輸液セッ 卜の使用が推奨されている9 .このことを受けて，20 滴 $/ \mathrm{mL}$ 規格のPVC フリーの輸液セットB を用いて滴容 量測定を行い，光の結果を表 6 に示した．また，点滴速 度を小さくかつ精密に管理するため, 微量点滴用のもの が用いられることも多いので , 60 滴 $/ \mathrm{mL}$ 規格の輸液セッ 卜bでの測定結果を表 7 に示した .

生理食塩液および中心静脈栄養輸夜(ネオパレン®2号) を用いて，界面活性作用を有する薬㓢配合による滴容量 への影響を調べた結果を表 8 に示した。

\section{2. 点滴速度の滴容量への影響}

生理食塩液をコントロール輸液剂として，20滴 $/ \mathrm{mL}$ の輸液セット $\mathrm{A}$ および 60 滴 $/ \mathrm{mL}$ の輸液セット aを用い て, 点滴速度の違いが滴容量へ与える影響を調べ, 光の 結果を図 2 に示した . 液滴の大きい輸液セットA は, 速度上昇に伴い滴容量が約 10\% 増大した後, プラトー

表 5 . 各種輸液斉の密度および粘度と 20 滴 $/ \mathrm{mL}$ 規格の輸液セットにおける滴容量

\begin{tabular}{|c|c|c|c|c|c|}
\hline $\begin{array}{c}\text { 㡏液剂”的 } \\
\text { No. }\end{array}$ & 製㟧名 & $\begin{array}{c}\text { 密度 } \\
(\mathrm{g} / \mathrm{mL})\end{array}$ & $\begin{array}{c}\text { 粘度 } \\
(\mathrm{mPa} \cdot \mathrm{s})\end{array}$ & 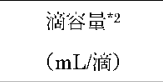 & 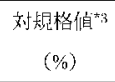 \\
\hline 1 & 人塚生食注 & 1.005 & 1.020 & $0.0532 \pm 0.0005$ & $106.4 \pm 0.9$ \\
\hline 2 & ラクテック西注 & 1.004 & 1.024 & $0.0527 \pm 0.0005$ & $105.4 \pm 1.0$ \\
\hline 3 & ポタコール $\mathrm{R}$ & 1.023 & 1.147 & $0.0525 \pm 0.0003$ & $105.0 \pm 0.6$ \\
\hline 4 & KN 䘞液 3B & 1.012 & 1.042 & $0.0527 \pm 0.0010$ & $105.4 \pm 2.1$ \\
\hline 5 & フィジオ140 & 1.009 & 1.026 & $0.0529 \pm 0.0006$ & $105.8 \pm 1.2$ \\
\hline 6 & フィジォ此35 & 1.040 & 1.362 & $0.0519 \pm 0.0004$ & $103.8 \pm 0.7$ \\
\hline 7 & トリフリード & 1.041 & 1.310 & $0.0522 \pm 0.0006$ & $104.4 \pm 1.1$ \\
\hline 8 & 低分けデキストランL注 & 1.043 & 4.855 & $0.0514 \pm 0.0004$ & $102.8 \pm 0.8$ \\
\hline 9 & 低分らデキストラン糖注 & 1.057 & 5.564 & $0.0507 \pm 0.0004$ & $101.4 \pm 0.8$ \\
\hline 10 & マルトズー10 & 1.035 & 1.299 & $0.0524 \pm 0.0004$ & $104.8 \pm 0.8$ \\
\hline 11 & 大䝅糖液 $10 \%$ & 1.036 & 1.303 & $0.0526 \pm 0.0004$ & $105.2 \pm 0.7$ \\
\hline 12 & 大恬糖液 $50 \%$ & 1.184 & 6.383 & $0.0474 \pm 0.0006$ & $94.8 \pm 1.3$ \\
\hline 13 & トリパレンタ1 多 & 1.090 & 1.950 & $0.0497 \pm 0.0002$ & $99.4 \pm 0.4$ \\
\hline 14 & トリバレン2 2 岁 & 1.112 & 2.555 & $0.0491 \pm 0.0008$ & $98.2 \pm 1.6$ \\
\hline 15 & アミバレンロ & 1.029 & 1.447 & $0.0480 \pm 0.0014$ & $96.0 \pm 2.8$ \\
\hline 16 & ソミノレバンャ & 1.023 & 1.299 & $0.0487 \pm 0.0006$ & $97.4 \pm 1.2$ \\
\hline 17 & アミノフリード & 1.040 & 1.372 & $0.0507 \pm 0.0000$ & $101.4 \pm 0.0$ \\
\hline 18 & ビーフリード祦滴静注:H & 1.040 & 1.328 & $0.0507 \pm 0.0002$ & $101.4 \pm 0.3$ \\
\hline 19 & アミノトリパ的1 号 & 1.073 & 1.766 & $0.0491 \pm 0.0007$ & $98.2 \pm 1.3$ \\
\hline 20 & アミノトリイ、㟧 & 1.086 & 1.997 & $0.0485 \pm 0.0007$ & $97.0 \pm 1.3$ \\
\hline
\end{tabular}

*1 : 表面張力に明らかに影響を与えることが予想されるポリソルベートや精製卵黄 レシチンなどの界面活性成分を含む輸液刘(No.21〜26)は除いた．

*2 : 輸液セッ卜 A〔JMS 輸液セッ卜 210 型(規格：20滴/ $\mathrm{mL}, \mathrm{PVC}$ )〕を用い, $250 \mathrm{~mL}$ /時間の点滴速度設定で測定。

室温 : $23 \pm 1^{\circ} \mathrm{C} . n=3$. Mean \pm S.D

*3 : 輸液セットの規格值 20 滴 $/ \mathrm{mL}=0.0500 \mathrm{~mL} /$ 滴に対する割合〔対規格值 $(\%)=$ 滴 容量 $(\mathrm{mL} /$ 滴 $) / 0.0500(\mathrm{~mL} /$ 滴 $) \times 100$ ]. 
表 6 . 中心静脈栄養輸液剂および脂肪乳斉の密度と 20 滴 $/ \mathrm{mL}$ 規格の輸液 セットにおける滴容量

\begin{tabular}{|c|c|c|c|c|}
\hline $\begin{array}{c}\text { 製品名 } \\
\text { (輸液剂 No.) }\end{array}$ & 混往溙剂 & $\begin{array}{c}\begin{array}{c}\text { 密谋 } \\
(\mathrm{g} / \mathrm{mL})\end{array} \\
\end{array}$ & $\begin{array}{c}\text { 滴容量”1 (mL/滴) } \\
\text { [点湳速度] }\end{array}$ & $\begin{array}{c}\text { 対規格值 }{ }^{ \pm 2} \\
(\%)\end{array}$ \\
\hline \multirow{2}{*}{$\begin{array}{c}ア ミ ノ ト リ ハ ゙ ~ \\
\text { (No.19) }\end{array}$} & - & 1.073 & $\begin{array}{c}0.0456 \pm 0.0010 \\
{[850 \mathrm{~mL} / 12 \text { 時筒] }]}\end{array}$ & $91.2 \pm 1.9$ \\
\hline & オーツカ MV 注 & 1.073 & $\begin{array}{c}0.0441 \pm 0.0005 \\
{[850 \mathrm{~mL} / 12 \text { 時問 }]}\end{array}$ & $88.2 \pm 1.0$ \\
\hline \multirow{2}{*}{ 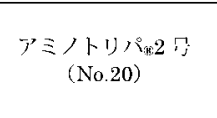 } & - & 1.086 & $\begin{array}{c}0.0452 \pm 0.0005 \\
{[900 \mathrm{~mL} / 12 \text { 時㩑 }]}\end{array}$ & $90.4 \pm 0.9$ \\
\hline & オーツカ MV注 & 1.087 & $\begin{array}{c}0.0435 \pm 0.0007 \\
{[900 \mathrm{~mL} / 12 \text { 時間 } 〕} \\
\end{array}$ & $87.0 \pm 1.3$ \\
\hline \multirow{2}{*}{$\begin{array}{c}\text { ネオハレンン1 吕 } \\
\text { (No.21) }\end{array}$} & & 1.053 & $\begin{array}{c}0.0468 \pm 0.0004 \\
{[1000 \mathrm{~mL} / 12 \text { 時閒 }]}\end{array}$ & $93.6 \pm 0.8$ \\
\hline & エレメンミッタツ注 & 1.054 & $\begin{array}{c}0.0462 \pm 0.0005 \\
{[1000 \mathrm{~mL} / 12 \text { 時間 }]}\end{array}$ & $92.4 \pm 1.1$ \\
\hline \multirow{2}{*}{$\begin{array}{c}\text { ホオパレンa 吕 } \\
\text { (No.22) }\end{array}$} & & 1.078 & $\begin{array}{c}0.0445 \pm 0.0003 \\
{[1000 \mathrm{~mL} / 2 \text { 時閒 }]}\end{array}$ & $89.0 \pm 0.6$ \\
\hline & エレメンミックの注 & 1.078 & $\begin{array}{c}0.0448 \pm 0.0003 \\
{[1000 \mathrm{~mL} / 12 \text { 時閣] }}\end{array}$ & $89.6 \pm 0.5$ \\
\hline \multirow{2}{*}{$\begin{array}{l}\text { ミキシッド代-L } \\
\text { (No.23) }\end{array}$} & & 1.058 & $\begin{array}{c}0.0457 \pm 0.0003 \\
{[900 \mathrm{~mL} / 12 \text { 時䦓 }]}\end{array}$ & $91.4 \pm 0.5$ \\
\hline & オーツカ $\mathrm{MV}$ 注 & 1.059 & $\begin{array}{c}0.0350 \pm 0.0006 \\
{[900 \mathrm{~mL} / 12 \text { 時問 }]}\end{array}$ & $70.0 \pm 1.1$ \\
\hline \multirow{2}{*}{$\begin{array}{c}\text { ミ本シッドィーH } \\
\text { (No.24) }\end{array}$} & & 1.074 & $\begin{array}{c}0.0453 \pm 0.0002 \\
{[900 \mathrm{~mL} / 12 \text { 時間 }]} \\
\end{array}$ & $90.6 \pm 0.4$ \\
\hline & オーツカ MV 注 & 1.076 & $\begin{array}{c}0.0347 \pm 0.0001 \\
{[900 \mathrm{~mL} / 12 \text { 時閜 }]}\end{array}$ & $69.4 \pm 0.2$ \\
\hline $\begin{array}{c}\text { イントラリボス } \\
\text { (No.25) }\end{array}$ & - & 0.995 & $\left.\begin{array}{l}0.0489 \pm 0.0009 \\
{[250 \mathrm{~mL} / 5 \text { 声閪 }]}\end{array}\right]$ & $97.8 \pm 1.7$ \\
\hline $\begin{array}{c}\text { イントラリポズ } \\
\text { (No.26) }\end{array}$ & - & 0.987 & $\begin{array}{c}0.0470 \pm 0.0033 \\
{[250 \mathrm{~mL} / 10 \text { 時間 }]}\end{array}$ & $94.0 \pm 6.6$ \\
\hline
\end{tabular}

${ }^{*} 1$ : 輸液セット B〔JMS 輸液セット 210 型(規格：20滴 $/ \mathrm{mL}, \mathrm{PVC}$ フリー)〕を用いて， 下段の点滴速度設定で測定。

室温 : $23 \pm 1^{\circ} \mathrm{C} . \mathrm{n}=3$. Mean \pm S.D.

$* 2$ : 輸液セットの規格值 20 滴 $/ \mathrm{mL}=0.0500 \mathrm{~mL} /$ 商に対する割合 [対規格值 $(\%)=$ 滴容 量 $(\mathrm{mL} /$ 滴 $) / 0.0500$ ( $\mathrm{mL} /$ 滴 $) \times 100]$.

表 7 . 中心静脈栄養輸液剂および脂肪乳斉の密度と 60 滴 $/ \mathrm{mL}$ 規格の輸液セットにおける滴容量

\begin{tabular}{|c|c|c|c|c|}
\hline $\begin{array}{c}\text { 輸液剂 } \\
\text { No. }\end{array}$ & 製品名 & $\begin{array}{c}\text { 密度 } \\
(\mathrm{g} / \mathrm{mL})\end{array}$ & 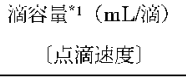 & $\begin{array}{c}\text { 刘规格值 }{ }^{2} \\
(\%)\end{array}$ \\
\hline 19 & デミノトリパ 品 & 1.073 & $\begin{array}{c}0.0156 \pm 0.0003 \\
{[850 \mathrm{~mL} / 12 \text { 時問 }]}\end{array}$ & $93.4 \pm \mathbf{1 . 5}$ \\
\hline 20 & ケミノトリパ政 号 & 1.086 & $\begin{array}{l}0.0153 \pm 0.0002 \\
{[900 \mathrm{~mL} / 12 \text { 膊間 }]}\end{array}$ & $91.6 \pm 1.4$ \\
\hline 21 & ネオパレン的号 & 1,053 & $\begin{array}{c}0.0158 \pm 0.0001 \\
\lceil 1000 \mathrm{~m} L / 12 \text { 封開 }]\end{array}$ & $94.6 \pm 0.6$ \\
\hline 22 & ネオバレン2， 岁 & 1.078 & $\begin{array}{c}0.0154 \pm 0.0001 \\
{[1000 \mathrm{~mL} / 12 \text { 封間 }]}\end{array}$ & $92.2 \pm 0.7$ \\
\hline 23 & ミキシッド船一L & 1.058 & $\begin{array}{l}0.0149 \pm 0.0003 \\
{[900 \mathrm{~mL} / 12 \text { 時间 }]}\end{array}$ & $89.2 \pm 1.6$ \\
\hline 24 & ミキシッド@ーH & 1.074 & $\begin{array}{c}0.0147 \pm 0.0003 \\
{[900 \mathrm{~mL} / 12 \text { 時問 }]}\end{array}$ & $88.0 \pm 1.6$ \\
\hline 25 & イントラリポス $10 \%$ & 0.995 & $\begin{array}{l}0.0163 \pm 0.0003 \\
{[250 \mathrm{~mL} / 5 \text { 時問 }]}\end{array}$ & $97.6 \pm \mathbf{1} .5$ \\
\hline 26 & 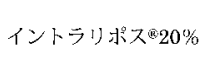 & 0.987 & $\begin{array}{c}0.0158 \pm 0.0009 \\
{[250 \mathrm{mT} / 10 \text { 時問 }]}\end{array}$ & $94.6 \pm 5.1$ \\
\hline
\end{tabular}

* 1 : 輸液セット b〔JMS 輸液セット 210 型(規格 : 60 滴 $/ \mathrm{mL}, \mathrm{PVC}$ フリー)〕を用い て, 下段の点滴速度設定で測定 .

室温 : $23 \pm 1^{\circ} \mathrm{C} . \mathrm{n}=3$. Mean \pm S.D

*2 : 輸液セットの規格值 60 滴 $/ \mathrm{mL}=0.0167 \mathrm{~mL} /$ 滴に対する割合 [対規格值 $(\%)=$ 滴容量 $(\mathrm{mL} /$ 滴 $) / 0.0500(\mathrm{~mL} /$ 滴 $) \times 100]$. 
表 8 . 界面活性成分を含む薬阂配合による滴容量への影響

\begin{tabular}{|c|c|c|c|c|}
\hline 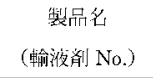 & 配合薬剂 & $\begin{array}{c}\text { 密度 } \\
(\mathrm{g} / \mathrm{mL})\end{array}$ & $\begin{array}{l}\text { 湳谷奄 } \\
\text { (mL/㹍) }\end{array}$ & $\begin{array}{l}\text { 刘コントロー } \\
\text { ル上比游*3 (\%) }\end{array}$ \\
\hline \multirow{5}{*}{$\begin{array}{c}\text { 大塚牛食沫: } \\
\text { (No.1) }\end{array}$} & (コントロール) & 1.005 & $0.0535 \pm 0.0006^{* 1}$ & \\
\hline & ケイツーツN 静注用 & 1.005 & $0.0529 \pm 0.0009^{* 1}$ & $98.9 \pm 1.7$ \\
\hline & 独力ネオミノファーゲンシー赭 & 1.006 & $0.0530 \perp 0.0009^{\circ 1}$ & $99.1 \perp 1.6$ \\
\hline & ラステット䣦 & 1.006 & $0.0428 \pm 0.0003^{* 1}$ & $80.0 \pm 0.4$ \\
\hline & サンディミユン畔上射液 & 1.007 & $0.0314 \pm 0.0006^{\star 1}$ & $58.8 \pm 1.2$ \\
\hline \multirow{5}{*}{$\begin{array}{c}\text { ネオパレン®2 岗 } \\
\text { (No.22) }\end{array}$} & －(コントロール $)$ & 1.078 & $0.0445 \pm 0.0003^{* 2}$ & - \\
\hline & ケイッー路注用 & 1.078 & $0.0448 \pm 0.0004^{* 2}$ & $100.6 \pm 0.9$ \\
\hline & 強力ネオミノファーゲンシー䟚 & 1.078 & $0.0441 \pm 0.0009^{\star 2}$ & $99.2 \pm 2.0$ \\
\hline & ラスデット睢 & 1.078 & $0.0364 \pm 0.0004^{x_{2}}$ & $8 \mathbf{1 . 7 \pm 0 . 9}$ \\
\hline & サンディミユン佃射液 & 1.078 & $0.0278 \pm 0.0003^{*_{3}}$ & $62.5 \pm 0.6$ \\
\hline
\end{tabular}

${ }^{*} 1$ : 輸液セット $\mathrm{B}(\mathrm{JMS}$ 輸液セット 210 型〔規格 : 20 滴 $/ \mathrm{mL}, \mathrm{PVC}$ フリー〕)を用いて， $250 \mathrm{~mL} /$ 時間の点滴速度設定で測定 . 室温 : $23 \pm 1^{\circ} \mathrm{C} . n=3$. Mean \pm S.D.

${ }^{*} 2$ : 輸液セット $\mathrm{B}(J \mathrm{MS}$ 輸液セット 210 型〔規格 : 20 滴 $/ \mathrm{mL}, \mathrm{PVC}$ フリー〕)を用いて, $1000 \mathrm{~mL} / 12$ 時間の点滴速度設定で測定 . 室温 : $23 \pm 1^{\circ} \mathrm{C} . \mathrm{n}=3$. Mean \pm S.D.

*3: Mean \pm S.D.

になっているのに対し, 液滴の小さい輸液セットaは， 低い速度の段階で滴容量がプラトーになり，また，増大 量も約 $5 \%$ と少ない結果となった .

\section{3. 輸液セットの種類による滴容量への影響}

生理食塩液をコントロール輸液剂として，20滴 $/ \mathrm{mL}$ 規格の輸液セット A，B，C，Dについて，250 mL/時間 の点滴速度での滴容量を比較した結果および 60 滴 $/ \mathrm{mL}$ 規格の輸液セット $\mathrm{a}, \mathrm{b}, \mathrm{c}, \mathrm{d}$ について, $100 \mathrm{~mL} /$ 時間 の点滴速度での滴容量を比較した結果を図 3 に示した . いずれにおいても，輸液セットの種類による滴容量への 影響はみられなかった .

\section{考察}

\section{1. 一般輸液斉の滴容量}

点滴筒内のノズルからの落滴は, 下向きの重力と液面 を保持する表面張力とのバランスで形成される .これら の因子と滴容量との間には液滴形成が一定速度の場合， 次式(1)が成り立つとされる3.

$$
V=F[2 \pi d / g \times \sigma / \rho]
$$

ここで, $V$ は滴容量 $(\mathrm{mL}), \mathrm{d}$ はノズル直径 $(\mathrm{cm}), \mathrm{g}$ は重 力加速度 $\left(\mathrm{cm} / \mathrm{s}^{2}\right), \sigma$ は表面張力 $(\mathrm{mN} / \mathrm{m}), \rho$ は密度 $(\mathrm{g} /$ $\mathrm{mL}), \mathrm{F}$ ( Harkins Brown correction factor $^{3}$ を示す. 同じ

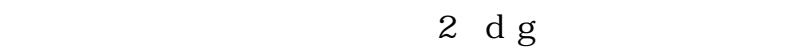
ことから，表面張力および密度が滴容量に及ぼす主な因 子として考えられる .

今回，20滴/ $\mathrm{mL}$ の輸液セットを用い $250 \mathrm{~mL} /$ 時間の 点滴速度で測定した各種輸液剂の滴容量(表 5)を密度に 対してプロットした結果を図4(密度との関係)に示し た . 各種輸液剂としては, 表面張力に明らかに影響を与 えることが予想されるポリソルベートや精製卵黄レシチ
ンなどの界面活性成分を含む輸液剂(No.21〜26)は除い たが, No.1〜20の輸液剂の滴容量と密度との相関は低 かった $(r=0.7089)$. しかし，アミノ酸を含まない輸液阂 (No.1 14)に限定すると， $r=0.9761$ と高い相関関係か認 められ, 密度の増加に反比例して滴容量が減少するとい う上記(1)式に従うことが確認された．アミノ酸を含む 輸液斉(No.15〜20)が，この関係から外れた理由として は, 中性アミノ酸で側鎖の疎水性が強いトリプトファン およびチロジンが $0.01 \mathrm{M}$ 以上の濃度で輸液剂中に含ま れることによって，柴山的らによって報告されている表 面張力 $(\sigma)$ の低下が生じ, 滴容量が減少したものと推察 された .

一方, No.1〜2O(表 5)の輸液剂の滴容量と粘度の相関 を図 4(粘度との関係)に示した．アミノ酸を含まない輸 液剂に限定すると $r=0.7406$ であり，粘度の増加に伴い 滴容量が減少する傾向が確認された . この傾向は, 次式 (2) に示すように粘度が密度に比例する因子であるため と考えられる .

$$
\eta=v \rho=K t \rho
$$

ここで, クは粘度 [絶対粘度 $(\mathrm{mPa} \cdot \mathrm{s})], v$ は動粘度 $\left(\mathrm{mm}^{2} /\right.$ $\mathrm{s}), \rho$ は密度 $(\mathrm{g} / \mathrm{mL}), \mathrm{K}$ は粘度計の定数 $\left(\mathrm{mm}^{2} / \mathrm{s}^{2}\right), \mathrm{t}(\mathrm{s})$ は 毛細管の流下時間を示す。

高い粘度を示すデキストラン 40 を含む輸液剂(No.8， 9)の滴容量が，これらより粘度は明らかに低いが密度の 大きい輸液斉(No.13，14)の滴容量より大きいことから， 液の粘度自体は滴容量にはほとんど影響しないと推察さ れた .なお，同樣の考察がグリセリン水溶液を用いた実 験において佐藤引らにより報告されている .

\section{2. 中心静脈栄養輸液剂, 脂肪乳斉の滴容量}

中心静脈栄養輸液剂, および比較的遅い点滴速度で速 度管理が必要な脂肪乳斉について, 臨床で用いられてい 
20 滴 $/ \mathrm{mL}$ 規格の輸液セット使用時

\begin{tabular}{|c|c|c|c|c|c|c|c|}
\hline 点湳速度 & $25 \mathrm{~mL}$ /特㸞 & $50 \mathrm{~mL}$ 特捳 & $100 \mathrm{~mL} /$ 侍师 & $150 \mathrm{~mL} /$ 時牒 & $200 \mathrm{~mL} /$ 侍附 & $250 \mathrm{~mL} /$ 時㑟 & $300 \mathrm{~mL} /$ 恃师 \\
\hline $\begin{array}{l}\text { 滴容量 } \\
\text { ( } \mathrm{mL} \text { 㹍) }\end{array}$ & $\begin{array}{c}0.0483 \\
\pm 0.0017\end{array}$ & $\begin{array}{c}0.0487 \\
\pm 0.0013\end{array}$ & $\begin{array}{c}0.0498 \\
\pm 0.0014\end{array}$ & $\begin{array}{c}0.0517 \\
\pm 0.0012\end{array}$ & $\begin{array}{c}0.0537 \\
\pm 0.0008\end{array}$ & $\begin{array}{c}0.0532 \\
\pm 0.0005\end{array}$ & $\begin{array}{c}0.0538 \\
\pm 0.0022\end{array}$ \\
\hline 刘梘格体 $2^{2 *}$ & 96.6 & 97.4 & 99.6 & 103.4 & 107.4 & 106.4 & 107.6 \\
\hline$(\%)$ & \pm 3.3 & \pm 2.6 & \pm 2.8 & \pm 2.4 & \pm 1.7 & \pm 0.9 & \pm 4.5 \\
\hline
\end{tabular}

点滴速度 (滴/分)

0

20

40

60

80

100

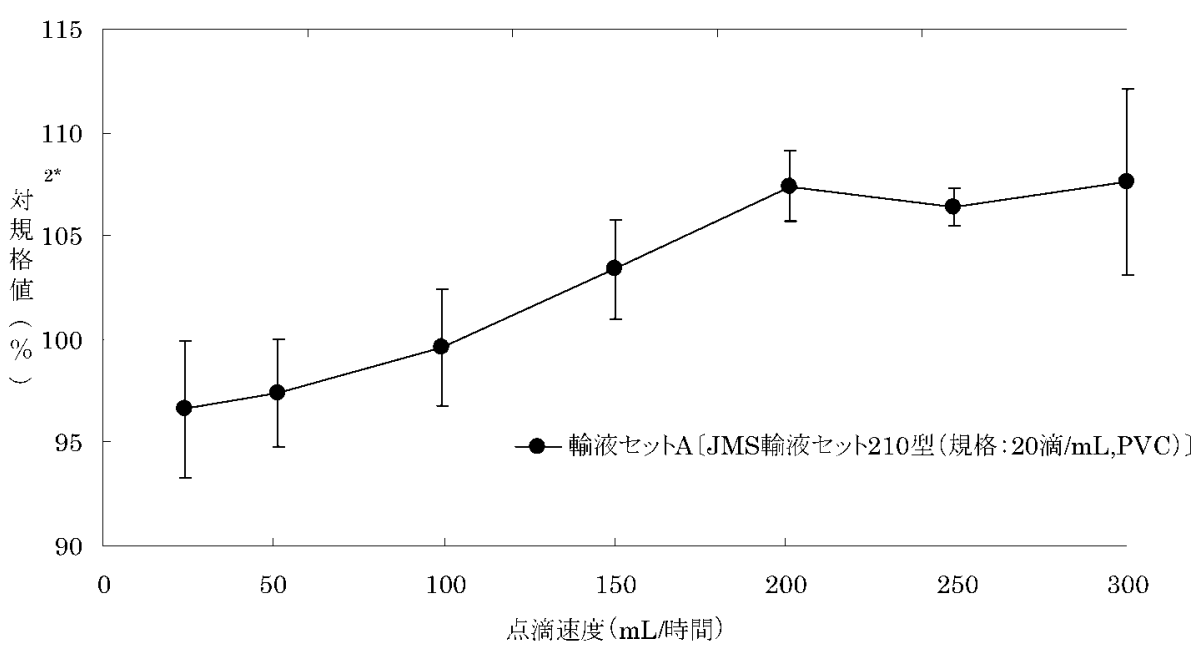

60 滴 $/ \mathrm{mL}$ 規格の輸液セット使用時

\begin{tabular}{|c|c|c|c|c|c|c|c|}
\hline 点滴速度 & $5 \mathrm{~mL} /$ 恃閒 & $10 \mathrm{~mL} / /$ 將間 & $25 \mathrm{~mL} /$ 特閒 & $50 \mathrm{~mL} /$ 㭙閒 & $67 \mathrm{~mL} / /$ 侍間 & $83 \mathrm{~mL} / /$ 特閒 & $100 \mathrm{~mL} /$ 時閣 \\
\hline 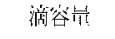 & 0.0163 & 0.0165 & 0.0170 & 0.0168 & 0.0170 & 0.0170 & 0.0170 \\
\hline 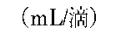 & \pm 0.0004 & \pm 0.0007 & \pm 0.0002 & \pm 0.0006 & \pm 0.0005 & \pm 0.0005 & \pm 0.0004 \\
\hline 刘規格值 & 97.6 & 98.8 & 101.8 & 100.6 & 101.8 & 101.8 & 101.8 \\
\hline$(\%)$ & \pm 2.4 & \pm 4.0 & \pm 1.0 & \pm 3.6 & \pm 1.7 & \pm 3.2 & \pm 2.1 \\
\hline
\end{tabular}

点滴速度 (滴/分)

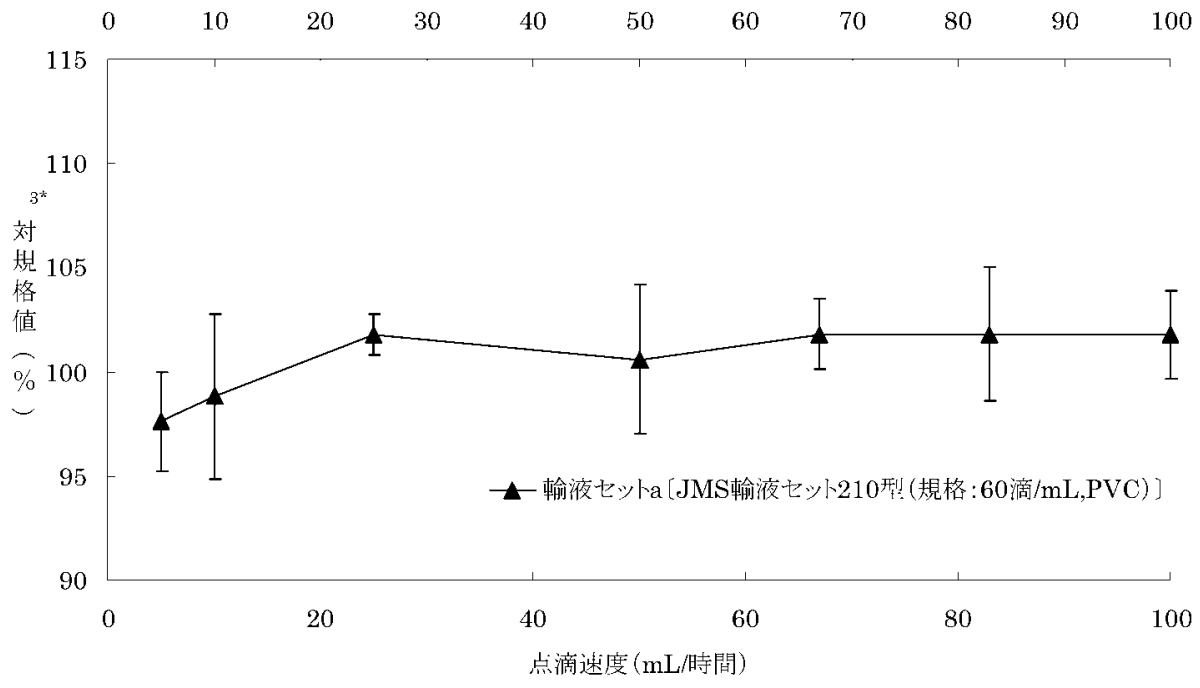

$1^{*}$ : 輸液斉は, 大塚生食注を使用. 室温 : $23 \pm 1^{\circ} \mathrm{C} . n=3$. Mean \pm S.D.

$2^{*}$ : 輸液セットの規格值 20 滴 $/ \mathrm{mL}=0.0500 \mathrm{~mL} /$ 滴に対する割合

〔対規格值 $(\%)=$ 滴容量 $(\mathrm{mL} /$ 滴 $) / 0.0500(\mathrm{~mL} /$ 滴 $) \times 100$ ]

室温 : $23 \pm 1^{\circ} \mathrm{C}, \mathrm{n}=3$. Mean \pm S.D.

$3^{*}$ : 輸液セットの規格値 60 滴 $/ \mathrm{mL}=0.0167 \mathrm{~mL} /$ 滴に対する割合

〔対規格值 $(\%)=$ 滴容量 $(\mathrm{mL} /$ 滴 $) / 0.0167(\mathrm{~mL} /$ 滴 $) \times 100$ ].

図 2 . 点滴速度の滴用量への影響1* 


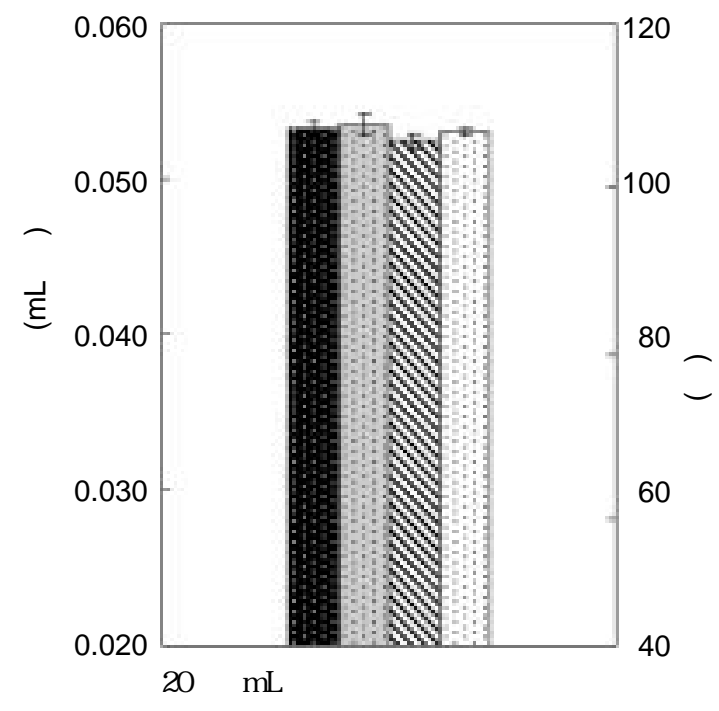

輸液セットA 輸液セット B

ベ輸液セット C $\quad::$ :輸液セット D

測定条件

輸液剂：大塚生食注

点滴速度 : $250 \mathrm{~mL} /$ 時間

室温 : $23 \pm 1^{\circ} \mathrm{C} . \mathrm{n}=3$.

* : 輸液セットの規格值 20 滴 $/ \mathrm{mL}=0.0500 \mathrm{~mL} /$ 滴に対 する割合〔対規格値 $(\%)=$ 滴容量 $(\mathrm{mL} /$ 商 $) / 0.0500$ $(\mathrm{mL} /$ 滴 $) \times 100$ ）.

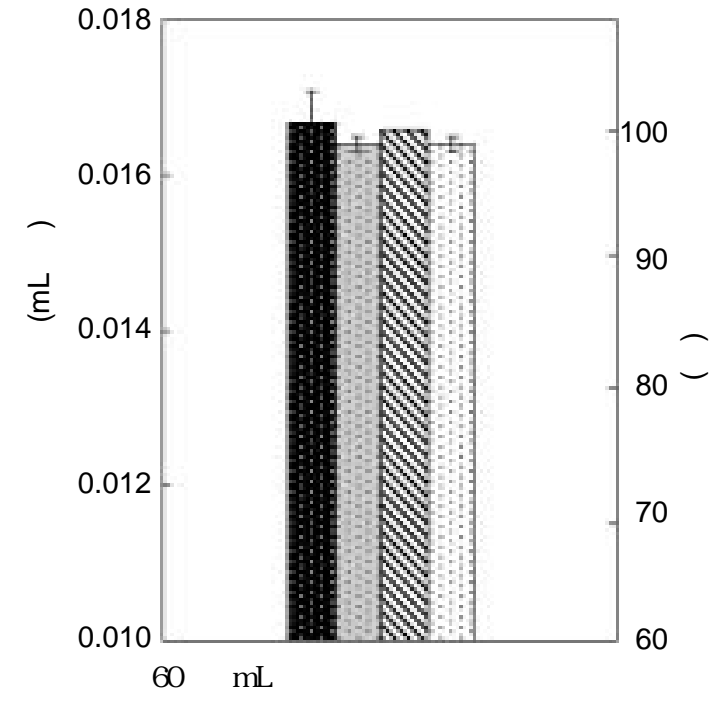

輸液セット a 輸液セット b

心輸液セット $\mathrm{c} ：$ : 輸液セットd

測定条件

輸液剂：大塚生食注

点滴速度 : $100 \mathrm{~mL} /$ 時間

室温 : $23 \pm 1^{\circ} \mathrm{C} . \mathrm{n}=3$.

* : 輸液セットの規格値 60 滴 $/ \mathrm{mL}=0.0167 \mathrm{~mL} /$ 滴に対 する割合〔対規格値 $(\%)=$ 滴容量 $(\mathrm{mL} /$ 滴) $/ 0.0167$ $(\mathrm{mL} /$ 滴 $) \times 100$ ）

図 3 . 輸液セットの違いによる滴用量への影響
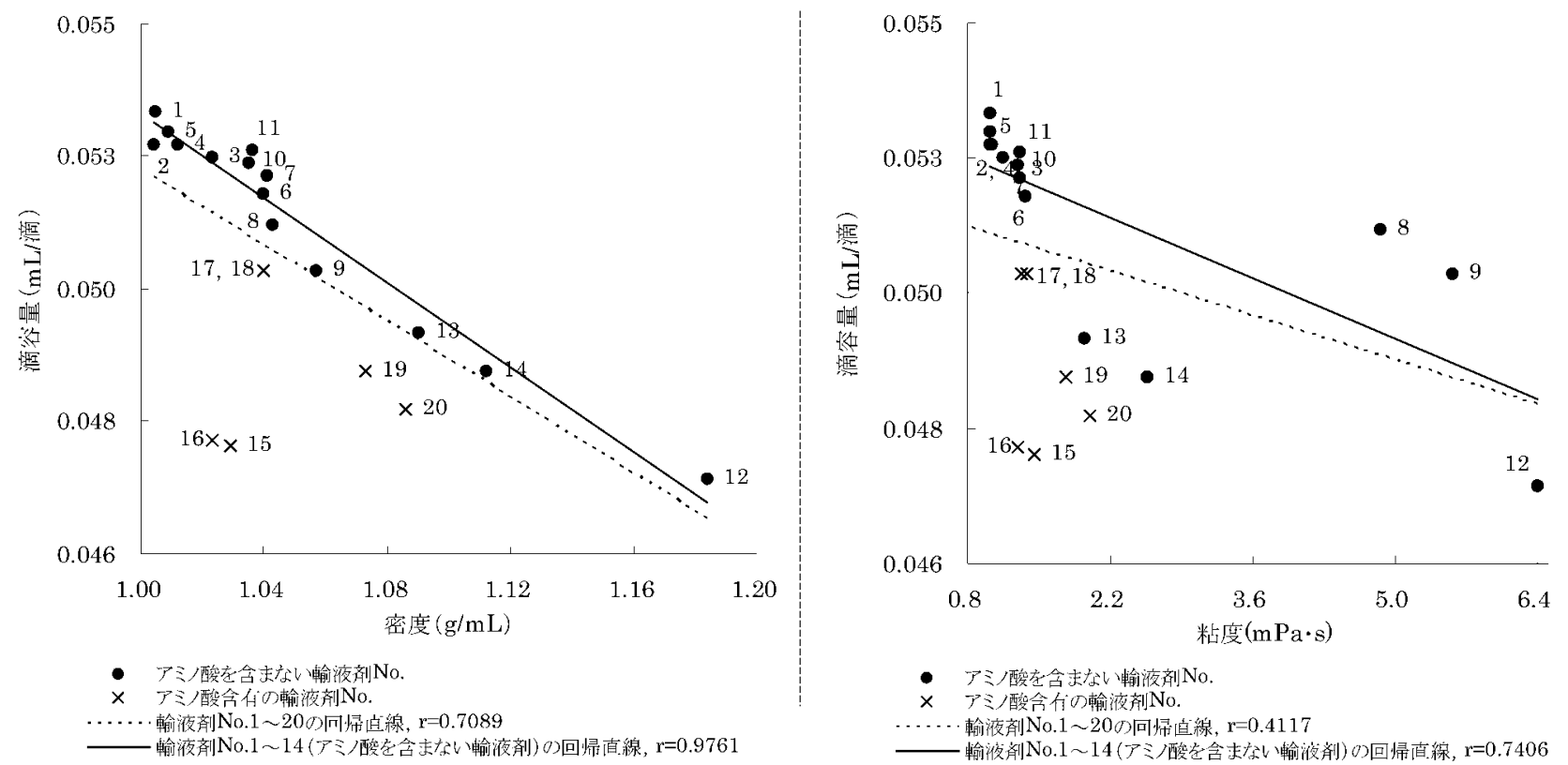

図 4 . 輸液斉の物性と滴容量との関係

る点滴速度に従い滴下したときの滴容量を測定した(表 6). また，これらの製剂は，微量点滴用の 60 滴 $/ \mathrm{mL} の$ 輸液セットが用いられることもあるため，これについて も同樣の点滴速度で滴容量を測定した(表 7). 表 6 で得
られた滴容量の対規格值を横軸に，表 7 で得られた滴容 量の対規格值を縦軸にとり,両者の相関関係を調べた(図 5). 兴の結果，対規格値 86〜100\% の範囲内において直 線関係が得られ，輸液セットの規格値に対する滴容量は 


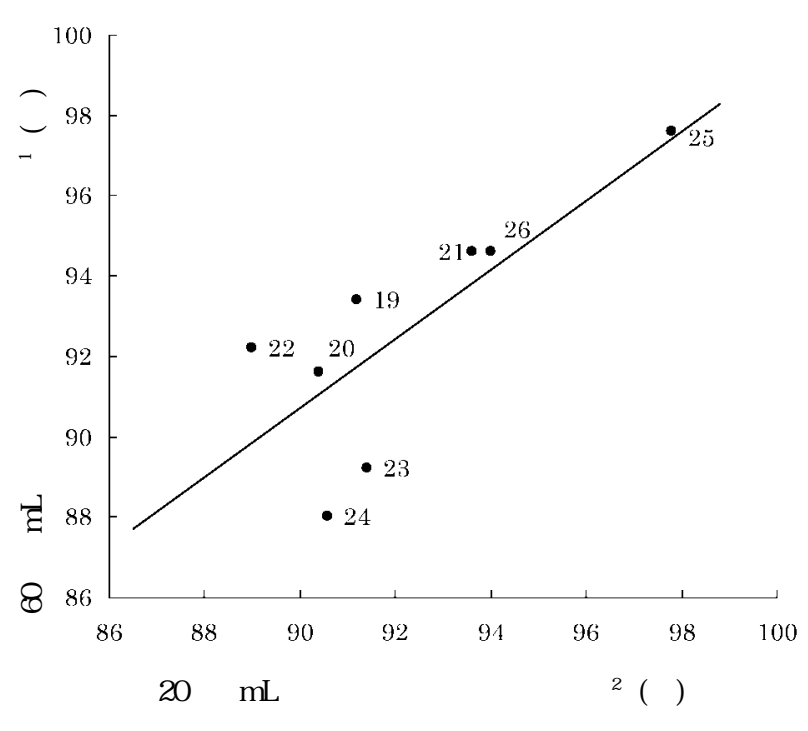

- 輸液剂 No.

—輸液剂 No.19 26 の回帰直線 $(y=0.862 x+13.126$, $r=0.7726)$

$1^{*}$ : 輸液セットの規格值 60 滴 $/ \mathrm{mL}=0.0167 \mathrm{~mL} /$ 滴に対する割合 〔対規格值 $(\%)=$ 滴容量 $(\mathrm{mL} /$ 滴 $) / 0.0167(\mathrm{~mL} /$ 滴 $) \times 100]$.

$2^{*}$ : 輸液セットの規格值 20 滴 $/ \mathrm{mL}=0.0500 \mathrm{~mL} /$ 滴に対する割合 〔対規格値 $(\%)=$ 滴容量 $(\mathrm{mL} /$ 滴 $) / 0.0500(\mathrm{~mL} /$ 滴 $) \times 100$ ]

図 5 . 輸液セットの規格違いによる滴容量への影響

20 滴 $/ \mathrm{mL}$ と 60 滴 $/ \mathrm{mL}$ の輸液セット間で違いを認めな かった．したがって，滴下制御方式の輸液ポンプを用い 成人を対象とした点滴速度という今回の試験条件では， 両者で同等の点滴速度管理が可能であると考えられた． このことは, 60 滴 $/ \mathrm{mL}$ の輸液セットは, 臨床上さらに 微量の点滴速度管理が要求される小児等を対象とした場 合に有用であることを示唆するものである .

中心静脈栄養輸液剂(No.19 24)は, 総合ビタミン剂 や微量元素製剂を輸液中に配合して点滴されることが多 いことから，これらを配合した場合の滴容量への影響を 検討した。輸液阂(No.19，20)に総合ビタミン剂を配合 した場合には，配合しなかったものに比べ滴容量が 3.0 $\%$ (No.19；0.0456 $\rightarrow 0.0441 \mathrm{~mL} /$ 商) , 3.4\% (No.20；0.0452 $\rightarrow 0.0435 \mathrm{~mL} /$ 滴)減少した .この理由は, 総合ビタミン 剂に含まれるポリソルベート -20 およびポリソルベー 卜-80の界面活性作用の影響と考えられる ${ }^{1 \text {, }}$. 輸液剂 (No.21，22)は，輸液自体にビタミンが配合されたキッ 卜製剤であることから，微量元素製剂を混合して产の影 響を調べた . 微量元素製剂は界面活性成分を含まないこ とから, 配合の有無による違いはみられなかった .— 方, 輸液斉(No.23，24)は脂肪を含む中心静脈栄養輸液 剂であるが，総合ビタミン剂の配合で滴容量が $20 \%$ 以 上(No.23;0.0457 $\rightarrow 0.0350 \mathrm{~mL} /$ 滴，No. $24 ; 0.0453 \rightarrow$ $0.0347 \mathrm{~mL} /$ 滴)減少し, 総合ビタミン剂を配合した点滴 使用に際しては，滴容量に特に注意する必要があると考 えられた。輸液剂(No.23，24)には脂肪の乳化剂として 界面活性作用をもつ精製卵黄レシチンが含まれており，
総合ビタミン剂に含まれるポリソルベートとの相乗効果 により著しい滴容量の減少がみられたものと思われる． すなわち，懸橋11らの界面活性斉の混合系における相乗 効果の報告のように，レシチンで形成されるイオン性ミ セル同士の静電反発を総合ビタミン剂に配合されている 非イオン界面活性剂(ポリソルベート)が緩和することに よって, 臨界ミセル濃度の減少が生じ，表面張力の大き な低下が起こり，著しい滴容量の減少につながったと推 察された .

\section{3. 界面活性成分を含む薬斉配合の影響}

生理食塩液(No.1)および中心静脈栄養輸液剂(No.22)に ついて，界面活性成分を含む薬剂を配合したときの滴容 量への影響を調べた(表 8). 界面活性成分の添加量の増 加に伴い, 滴容量の減少がみられた。特に, ラステッ 卜注(ポリソルベート $-80,400 \mathrm{mg}$, 日本化薬(株))およ びサンディミュン ${ }^{\circledR}$ 注射液(ポリオキシエチレンヒマシ 油， $3.25 \mathrm{~g}$ ，ノバルティスファーマ(株))では，いずれの 輸液剂でもコントロールに比べて著しい滴容量の減少が みられた．したがって, 輸液斉の点滴に際しては, 配合 薬剂による滴容量への影響にも注意を払う必要があるも のと考えられた .

\section{4. 点滴速度の滴容量への影響}

点滴速度が变動する場合, 式(1)に挙げられる滴容量 の変動要因(密度および表面張力)に加え, 点滴速度も滴 容量に影響を及ぼすことが知られている゙，光こで，ノ ズル口径の異なる 20 滴/ $\mathrm{mL}$ の輸液セットおよび 60 滴/ $\mathrm{mL}$ の輸液セットを用いて, 生理食塩液(No.1)の点滴速 度の滴容量への影響を調べた(図 2) . いずれの輸液セッ 卜においても点滴速度が上昇するにつれ滴容量が増加 し，ある点滴速度からは一定となる傾向か認められた . すなわち，20滴/mL の輸液セットでは， $25 \mathrm{~mL} /$ 時間(8 滴/分)の点滴速度で滴容量(対規格值)が $96.6 \%$ であった ものが,点滴速度の上昇に伴い滴容量は増加し, $200 \mathrm{~mL} /$ 時間(67滴/分)で 107.4\% となり，弚れ以降はほぼ一定 となった。また， 60 滴 $/ \mathrm{mL}$ の輸液セットでは, $5 \mathrm{~mL} /$ 時間(5滴/分)の点滴速度で滴容量(対規格值)が 97.6\% で あり，徐々に増加し，25 mL/時間(25滴/分)で 101.8\% となり，弚れ以降はほぼ一定となった。

点滴速度上昇に伴う滴容量か増加する原因は，液滴を 形成する点滴筒内のノズル部分において, 液滴が分離す る瞬間に液滴内に流入する薬液の量が, 点滴速度の上昇 に伴って増加したためと推察される. 佐藤引らも $85 \%$ グ リセリン水溶液を用いて流速の上昇に伴う液滴の体積の 増加を報告している．なお，点滴速度上昇に伴う滴容量 は，60滴 $/ \mathrm{mL}$ の輸液セットでは約 $5 \%$ の増加で一定に 達したが，20滴/mL の輸液セットでは約 10\% の増加で 一定に達し，ほぼ2倍の増加幅であった . これは，液滴 弚のもののサイズの違いに起因するものと考えられた . 
本研究では,輸液セット等の $1 \mathrm{~mL}$ あたりの滴数規格 が統一されたことを受け，各種輸液療法に用いられる 種々の輸液剂を対象として, 点滴時の滴容量を検討し た。弚の結果, 各種輸液剂において薬液の密度, 界面活 性成分の有無(表面張力)および点滴速度の違いが滴容量 に影響を及ぼすことを確認した . 点滴施行時にはこれら の点に留意する必要があると考えられることから，本研 究が, 臨床現場における輸液管理の上で, 有用な情報と なることを期待する .

\section{引用文献}

1) 木村利美, 黑山政一, 加賀谷肇, 朝長文弥, 大場正己， 輸液剂の点滴速度に与える添加薬剂の影響, 外科と代 謝・栄養 , 26, 159-165 (1992).

2) 木村利美, 朝長文弥, 注射斉における点滴速度のコント ロール , Pharm. Tech. Japan, 9, 85-88 (1993).

3) 佐藤光太郎, 廣瀬智水, 古屋浩二, 液滴形成過程の高速 度撮影，可視化情報学会論文集，26，62-68 (2006).
4) 大村知子, 藤澤浩美, 室親明, 山下典子, 黑田訓宏, 濱 口常男, 門林宗男, 輸液ポンプ使用時のパクリタセル 注射溶液の点滴速度に影響する要因について, 医療薬 学, 34, 467-473 (2008).

5) 厚生労働省医薬食品局, 医薬品・医療機器等安全性情報 No.235, 2007 年 4 月.

6) “第十五改正日本薬局方解説書”, 廣川書店, 2006, pp.B358-366.

7) “第十五改正日本薬局方解説書”, 廣川書店, 2006, pp.B320-340.

8) 日本工業規格 JIS T 0601-2-24, 医用電気機器 - 第 2-24 部 : 輸液ポンプ及び輸液コントローラの安全に関する個 別要求事項，2005年 3 月 25 日.

9）厚生労働省医薬食品局, 医薬品・医療機器等安全性情報 No.182, 2002 年 10 月.

10）萩野圭三, 山内仁史, 柴山俊朗, アミノ酸水溶液の界面 化学的性質, 油化学, 31, 1009-1013 (1982).

11）懸橋理恵, 界面活性斉混合系の相乗効果, 科学と工業, 80, 380-385 (2006). 